\title{
A Study on Women's Perception of Glass Ceiling in the Private Organizations, Pokhara
}

\author{
Ms. Barsha Rana
}

\begin{abstract}
The study is intended to explore women's perception of glass ceiling in the private organizations of Pokhara. Hundred women with different age groups working in different private organizations of Pokhara were taken as the sample. Their perception on the disparate treatment of women in organizations, behavior of their male colleagues towards them, the role of their family members in their professional growth, perception of role conflict and their aspiration towards their career advancements were asked and have been analyzed to find out if women perceive the existence of glass ceiling. In this regard, viewpoints of their male counterparts have also been taken into consideration.
\end{abstract}

Key words : perception, glass ceiling, women

\section{Introduction}

“GLASS CEILING” REFERS TO transparent but real barriers, based on discriminatory attitudes or organizational bias, that impede qualified individuals, including (but not limited to) women, racial and ethnic minorities, and disabled persons, from advancing into management positions. The term "glass ceiling", first used in a 1986 Wall Street Journal special report on the business women described a corporate world in which access to the top for women was blocked by company tradition and prejudice. The dramatic changes in women's work patterns since the 1960s include a growth in the proportion of women entering the formerly male-dominated field of work life. But, women are more likely to be found in traditionally female occupations like service and low level positions.

\section{Literature Review}

\section{Existence of Glass Ceiling}

An evidence of a Greece study conducted amongst women in management by A. P. Kottis (1996) shows that in spite of the continuous growth in the number of women in business schools only a small percentage of women since are found in managerial positions and their entry into the managerial ranks is much lower compared to that of their male counterparts. In a survey of 280 firms, women represented less than 25 percent of workforce. In 94 percent of the firms, the president of the board was a man. Even looking at an advanced country like UK, workplace is gendered. According to the 1998 research of A. Eyring and B. A. Stead in the Metropolitan District Council situated in Yorkshire, UK where 66 percent of the workforce were women and yet the majority of them occupied the lower range of the white collar posts. Even Margaret Gibelman's (2000) research on full-time employees of 74 non-profit agencies throughout the United States indicated that females were overrepresented in direct-service positions.

All these studies confirmed that women's progression was held back through the managerial ranks because of a lack of career counseling at all stages in their careers, conflicts between personal and work life, lack of management development for women, motherhood, traditions and socialization. 


\section{Methodology of the Study}

As the main purpose of the study is to discover facts and insights on the research topic, and as the study is at its primary stage, exploratory research design has been chosen. All types of female employees currently working in the private commercial firms as well as those female workers who have recently left the firms to pursue work in other private commercial firms of Pokhara, Kaski is the population of the study. While the focus of the research is on women, the sample included males as well. The sample size of the study was limited to 200 employees, out of which 100 were female and another 100 were male employees respectively. Random sampling was used whereby 100 each female and male employees were taken randomly from the private commercial sectors that included small shops as well as large industries. The research data was collected utilizing close-ended questionnaire. Two different sets of questionnaires were designed to elicit information separately from males and females.

\section{Objectives of the Study}

The overall objective of the research is to study women's perceptions and attitudes to their career and the work environment. The specific objectives are as follows:

- To find out women's pre-entry status and their choice of career

- To assess the role of family and family members in women's career progression

- To assess women's perception on role conflict in terms of balancing home and work life

- To find out the perceptions of women on the disparate treatment of women in organizations

To find out the attitudes and behavior of superiors, peers, subordinates and sexual harassment

- To see if women perceive career advancement opportunities and barriers in organizations

\section{Analysis}

\subsection{Pre and Post Entry Status of Working Women}

Earlier though men were considered as the breadwinners of the families, today women have also started contributing towards their family income. In the studies a majority of female respondents (38\%) stated that the main reason for them to work in offices was to utilize their education and skills. Almost 60 percent of them expected to match their work with their education level and skills but only 31 percent feels that their present jobs perfectly matched with their educational qualification and skills. Intrinsic factors motivates women than extrinsic factors.

\subsection{Role of Family Members in Women's Career Progression}

Socialization of girls in Nepalese culture has had such a great impact on women that they, in turn, consciously or unconsciously, enforce the patriarchal system. In the study, most of the women respondents believed that one of the major reasons for women's professional backwardness is the conservative behavior of family towards women.

\section{2.a Source of Inspiration}

Forty-six percent women state self-motivation as the main source of inspiration for them to begin earning for themselves. Many also consider their mother (28\%) as a great source of inspiration followed by fathers (21\%). For many married women employees even husbands $(21 \%)$ have stimulated them to go ahead with their work life. 


\section{2.b Attitude of Male Members on Women's Job}

Men and women have similar attitudes regarding women's association to their jobs. Though only a few men (10\%) strongly agreed and another five percent agreed that they did not like the female members of their families working outside the house, majority of them $(42 \%)$ had no problem if their mother, sister(s) or other female family members engaged themselves at work outside their families.

\section{2.c Sharing the Household Work}

Every woman has a dual role to play. In our traditional patriarchal society men need not spend as much of time as women in domestic chores. However, with the changes in time and attitude the traditional gender roles have also taken a transition. The above analysis shows that men support women in their professional life but do they help women in carrying out the household chores? Contradictory perception exists between men and women. Majority of men (40\%) said they offered a helping hand in the family to carry out the household activities but only and 21 percent of women strongly believe that apart from working in offices, they take care of the entire household tasks by themselves.

\subsection{Role Conflict}

As women play dual roles most of the times, there are chances that they perceive incompatibility between the role-requirements at home and office. Twenty six percent of female workers hold the belief that their connection to offices outside their house has never ever affected their personal lives and responsibilities at home. Almost same number of women $(24 \%)$ considers that their work outside the house, to some extent, affects their performance at home.

\subsection{Perception of Disparate Treatment of Women in Organizations}

Invisible and visible barriers, real or perceived, may exist in the organizations that appear to block the career advancement opportunities of women.

\section{4.a Discrimination in Organizational Policy}

In comparison to women (18\%), men (42\%) strongly disagree that their organizational policy makes any discrimination on gender basis. A very few (5\%) but equal number of female and male employees strongly agree that discrimination in policies are present in their organizations. Such discrimination is perceived by male members working in service sectors and female respondents working in the manufacturing sectors.

\section{4.b Involvement in Difficult and Important Decision Making}

Perception of discrepancy in decision making between male and female employees exists in organizations. Both male and female respondents believes that male employees definitely are more involved in making important decisions of organizations.

\section{4.c Equal Opportunities for Personal Development}

Women of different age groups working in varied organizations perceive no gender discrimination but provision of equal self-development opportunities.

\subsection{Behavior of Male Colleagues}

To find out if the social environment is conducive for women employees and if male colleagues' behavior is favorable towards their female colleagues the study inquires and 
analyzes the attitude of male colleagues towards their female colleagues. A majority of the male members (42\%) are of the viewpoint that they provide assistance to their female colleagues. Even most of the women (42\%) agree they receive assistance from their male friends in office.

\subsection{Perception of Sexual Harassment}

More than 75 percent of the total respondents (both male and female) have not come across any such unpleasant incidents which show that our private organizations are rather safe in terms of physical and verbal annoyance. However, organizations are not totally free of such nuisance. Though only a small number (6\%) admitted to presence of harassment towards women at one time or another.

\subsection{Perception of Women's Career Advancement Opportunities and Barriers}

There is a positive attitude towards women's advancement and professional growth. Majority of women blame our socio-cultural aspects for women's professional backwardness. For 64 percent of women, family will not stand as an obstacle in their career. Younger female workers are more interested in accepting new challenging jobs than the older ones.

\subsection{Attitude towards Change in Women's Traditional Roles}

All the women who are firm on picking up a profession than being a homemaker are of the opinion that if women could acquire as much of privileges as that of men they could definitely be in the position to occupy the upper status in organizations. Even the majority of women who choose to be a homemaker are confident that women have the potential to carry out jobs that are in the upper stratum of any profession if better opportunities are given to them. Even the third category of women who seem confused in themselves and cannot decide if they would choose their profession or household job are confident that women with proper education and environment can perform much better. More men than women employees are of the opinion that women should keep their professional goals alive and strive to achieve them.

\section{Conclusions}

- Intrinsic factors motives women than extrinsic factors to take up a professional career. Self-motivation is the main source of inspiration for women to be engaged in organized work.

- Family Support is evident to women's professional growth. A majority of women do not face role conflicts in handling their personal and professional lives.

- Women do not perceive Glass Ceiling in organizations to a large extent.

- Behavior of male employees towards women in offices is perceived as positive. A majority of women disagree that men are more capable and talented than them in performing office work. Perception on sexual harassment towards women does not exist to a large extent in private organizations in Pokhara. However, such cases are not nil.

- There is a positive attitude towards women's advancement and professional growth. Majority of women blame our socio-cultural aspects for women's professional backwardness. Younger age groups and female workers are more interested in accepting new challenging jobs than the older ones.

- The attitude of women respondents is stronger than men in the belief that women have the capability of performing challenging and risky jobs than just sticking to traditional 
roles. A majority of women also feel that given the opportunities there will be more women in the upper strata of professions than they are at present.

\section{REFERENCES}

Arfken, D. E. and et. al.. 2004. 'The Ultimate Glass Ceiling Revisited: The Presence of Women on Corporate Boards', Journal of Business Ethics, 50: 177-186.

Brockbank, Anne. and Traves, J. 1995. 'Career Progression of Female Managers in Retailing', Women in Management Review, 10(4): 4-10.

Daily, C. M. and et. al.. 1999. 'A Decade of Corporate Women: Some Progress in the Boardroom, None in the Executive Suite', Strategic Management Journal, 20: 93-99.

Eyring, A. and Stead, B. A. 1998. 'Shattering the Glass Ceiling: Some Successful Corporate Practices', Journal of Business Ethics, 17: 245-251.

Gibelman, M. 2000. 'The Nonprofit Sector and Gender Discrimination: A Preliminary Investigation into the Glass Ceiling', Non-profit Management and Leadership, 10(3): 251-269.

Jackson, J. C. 2001. 'Women Middle Managers' Perception of the Glass Ceiling', Women in Management Review, 16(1): 30-41.

Keeton, K. B. 1996. 'Characteristics of Successful Women Managers and Professionals in Local Government: A National Survey', Women in Management Review, 11(3): 27-34.

Kottis, A. P. 1996. 'Women in Management and the Glass Ceiling in Greece: an Empirical Investigation', Women in Management Review, 11(2): 30-38.

Lane, N. 2000. 'The Low Status of Female Part-Time NHS Nurses: A Bed-Pan Ceiling?', Blackwell Publishers Ltd., 7(4): 269-281.

Lane, Nikala. 2000. 'The Low Status of Female Part-Time NHS Nurses: A Bed-Pan Ceiling?', NonProfit Management and Leadership, 7(4): 269-281.

Large, M. and Saunders, M. N. K. 1995. 'A Decision-making Model for Analysing how the Glass Ceiling is Maintained: Unblocking Equal Promotion Opportunities', The International Journal of Career Management, 7(2): 21-28.

Liff, S. and Ward, K. 2001. 'Distorted Views through the Glass Ceiling: The Construction of Women's Understandings of Promotion and Senior Management Positions', Gender, Work and Organizations, 8(1): 19-36.

Linehan, M. and Walsh, J. S. 1999. 'Senior Female International Managers: Breaking the Glass Border', Women in Management Review, 14(7): 264-272.

Maxwell, G. A. 1997. 'Hotel General Management: Views from above the Glass Ceiling', International Journal of Contemporary Hospitality Management, 9/5/6: 230-235.

Mitra, A. 2003. 'Breaking the Glass Ceiling: African-American Women in Management Positions', Equal Opportunities International, 22(2): 67-79.

Nath, D. 2000. 'Gently Shattering the Glass Ceiling: Experiences of Indian Women Managers', Women in Management Review, 15(1): 44-55.

Roldan, M. and et. al.. 2004, 'Perceptions of Chilly IT Organizational Contexts and their Effect on the Retention and Promotion of Women in IT', Sigmis, 4: 108-113.

Simpson, R. and A. Yochanan. 2000. 'The Time Bounded Glass Ceiling and Young Women Manager: Career Progress and Career Success Evidence from the UK', Journal of European Industrial Training, 24/2/3/4: 190-198.

Tokunaga, H. and Graham, T. 1997. 'Tracking Career Progress for Minorities and Women: The Glass Ceiling', IEEE Potentials, 17-23.

Twomey, A. M. and et. al.. 2002. 'Career Progression of Young Female Accountants: Evidence from the Accountancy Profession in Ireland', Journal of Europeon Industrial Training, 26/2/3/4: 117-124.

Yuan, C. and Kleiner, B. H. 1999. 'Sex Discrimination in Hiring: The Glass Ceiling', Equal Opportunities International, 18(2/3/4): 51-55. 